\title{
SIMULASI PENGHITUNGAN ONLINE KREDIT PEMILIKAN RUMAH BANK XYZ BERBASIS WEB DI PORTAL FINANSIAL WWW.KONTAN.CO.ID
}

\author{
Albert V. Dian Sano \\ Information Systems Department, School of Information Systems, Binus University \\ Jl. K.H. Syahdan No. 9, Palmerah, Jakarta Barat 11480 \\ albert_vds@yahoo.com
}

\begin{abstract}
The objective of this study is to develop an online application of mortgage loan simulation. This application is developed based on a web application in order to be accessible anywhere and anytime. This application is expected to help prospective property's consumers calculate their financial plans related to decisions concerning the amount of down payment, loan term, and the mortgage system model to be selected. There are two models of mortgage in this application. The first is a fixed and cap rate of interest, with the first three years of the mortgage interest rate of $9.75 \%$, the fourth and fifth year interest of $10 \%$, and the sixth year onwards using a rate cap interest with the indication of $12 \%$. The second model is a 2-year fixed rate mortgage with the first two years rate of $8.5 \%$ and the third year onwards using adjustable rate mortgage of interest with the indication of $12 \%$. Calculation formula and the interest rates in this application are obtained from Bank XYZ which is in turn applied in collaboration with financial portal www.kontan.co.id. This application has been tested by over 1000 users and the results are well proven and valid.
\end{abstract}

Keywords: simulation mortgage calculation, web-based applications, properties

\begin{abstract}
ABSTRAK
Tujuan penelitian ini adalah untuk membuat aplikasi simulasi penghitungan Kredit Perumahan Rakyat (KPR) online. Aplikasi ini dikembangkan berbasis web supaya bisa diakses dari mana saja dan kapan saja. Aplikasi ini diharapkan bisa membantu para calon konsumen properti menghitung rencana keuangan mereka yang berhubungan dengan pengambilan keputusan mengenai besarnya uang muka, jangka waktu cicilan, dan model sistem KPR yang akan dipilih. Model sistem KPR dalam aplikasi ini ada dua. Yang pertama adalah berbasis suku bunga Fixed and Cap, dengan suku bunga cicilan tiga tahun pertama 9,75\%, pada tahun keempat dan kelima 10\%, dan tahun keenam dan seterusnya menggunakan suku bunga mengambang dengan indikasi cap sebesar 12\%. Yang kedua adalah suku bunga fixed dua tahun dengan bunga cicilan dua tahun pertama 8,5\% dan tahun ketiga dan seterusnya menggunakan indikasi suku bunga sebesar $12 \%$. Rumus penghitungan dan suku bunga dalam aplikasi ini adalah dari Bank XYZ yang pada gilirannya diaplikasikan dengan bekerja sama dengan portal finansial www.kontan.co.id. Aplikasi ini sudah dicoba oleh lebih dari 1000 pengguna dan hasil penghitungan sudah berhasil dengan baik dan valid.
\end{abstract}

Kata kunci: simulasi penghitungan kredit pemilikan rumah, aplikasi berbasis web, properti 


\section{PENDAHULUAN}

Tahun 2012 ini kinerja penjualan properti di Indonesia sangat tinggi. Bahkan kinerja properti Indonesia kuartal satu adalah yang terkuat di kawasan Asia Pasifik, mengalahkan Malaysia, India, China, Selandia Baru, Korea Selatan dan Australia (Amri, Indreswari, Dori, 2012). Ini berarti konsumen properti sangat banyak di Indonesia. Dalam proses pembelian properti, pada umumnya calon konsumen diberikan beberapa jenis model pembayaran. Ada yang tunai keras, tunai bertahap, dan cicilan dengan menggunakan uang muka dengan jumlah tertentu. Model pembayaran paling umum dan paling banyak digunakan adalah dengan menggunakan cicilan dan uang muka. Ini bisa dimaklumi karena konsumen properti di Indonesia kebanyakan didominasi oleh kelas menengah yang mempunyai daya beli yang baik melalui sistem pembayaran cicilan.

Sementara itu, pembayaran cicilan juga menarik minat bisnis berbagai lembaga keuangan dan perbankan. Karena dipicu tingkat kompetisi yang terus meningkat, lembaga-lembaga keuangan juga menawarkan berbagai macam variasi dalam model pembayaran cicilan kepada konsumen. Ada yang menggunakan basis penghitungan suku bunga fixed untuk dua tahun pertama dan tahun-tahun berikutnya mengikuti basis hitungan suku bunga berdasarkan suku bunga yang berlaku di pasar. Ada juga yang menggunakan basis hitungan suku bunga berdasarkan kombinasi suku bunga fixed and cap. Suku bunga fixed adalah suku bunga di mana pembayaran bulanan tidak berubah terlepas dari apa yang terjadi pada tingkat suku bunga pasar (Keown, 2010:278). Kebalikan dari suku bunga fixed adalah suku bunga mengambang atau adjustable-rate morgages (ARM). Suku bunga mengambang atau $A R M$ adalah suku bunga yang berfluktuasi menurut tingkat suku bunga yang berlaku di pasar dalam batas interval tertentu (Keown, 2010: 279). Salah satu terminologi yang digunakan dalam ARM adalah rate cap. Rate cap membatasi seberapa besar suku bunga dalam ARM bisa berubah. (Keown, 2010: 280). Kombinasi suku bunga fixed and cap berarti bahwa selama periode tertentu, misalnya dua atau tiga tahun pertama, menggunakan basis hitungan suku bunga fixed dan tahun-tahun berikutnya menggunakan basis hitungan berdasarkan suku bunga yang berlaku di pasar namun tetap mengacu pada batas atas yang ditawarkan (cap).

Berbagai macam pilihan model sistem pembayaran dengan berbagai macam metode penghitungan sedikit banyak tentunya akan membingungkan calon konsumen. Bagi calon konsumen, semakin banyak pilihan akan menyebabkan semakin lama untuk mengambil keputusan. Campbell dan Cocco (2010:4) dalam penelitiannya bisa disimpulkan bahwa rumah tangga itu sangatlah heterogen dalam banyak hal, misalnya karakteristik manusianya, kenaikan harga rumah yang diharapkan di masa mendatang, tingkat risiko dan pemilihan waktunya. Heterogenitas yang demikian bisa saja mempengaruhi jenis Kredit Pemilikan Rumah (KPR) yang akan mereka pilih (Campbell dan Cocco, 2010:21). Secara alami perilaku konsumen akan memilih metode mana yang paling menguntungkan bagi dirinya. Sementara itu calon konsumen masih banyak yang awam dan belum terlalu memahami bagaimana cara menghitung sistem pembayaran yang akan mereka gunakan, terutama calon konsumen yang baru pertama kali berencana membeli properti. Ketidaktahuan ini akan menyebabkan cost yang tinggi dalam pengertian waktu. Waktu akan banyak tersita untuk memperoleh pengetahuan mengenai cara penghitungan pembiayaan KPR dan membanding-bandingkan pilihan mana yang menghasilkan penghitungan yang paling maksimal dilihat dari aspek keuangan pribadi. Dengan aplikasi simulasi online penghitungan KPR ini akan meningkatkan efisiensi waktu baik waktu dari sisi calon konsumen, penjual maupun dari pemberi kredit.

Berkaitan dengan hal tersebut, perlu adanya suatu aplikasi simulasi penghitungan KPR berbasis web untuk memudahkan calon konsumen dalam mengetahui hasil penghitungan secara mudah dan cepat di manapun berada sepanjang ada koneksi internet. Aplikasi ini bertujuan untuk memudahkan penghitungan baik di sisi konsumen, di sisi penjual, maupun penyedia jasa keuangan pemberi kredit seperti perbankan. Dengan kemudahan seperti ini diharapkan calon konsumen properti 
bisa menyiapkan anggaran keuangannya dengan lebih baik. Dalam penelitian ini, simulasi penghitungan KPR adalah berdasarkan formula penghitungan, jangka waktu cicilan dan suku bunga kredit dari Bank XYZ dan diimplementasikan di portal finansial www.kontan.co.id.

\section{METODE}

Metode yang digunakan dalam penelitian ini adalah knowledge acquisition, analisis kebutuhan pengguna terhadap sistem, dan perancangan basis data yang akan digunakan dalam simulasi penghitungan KPR ini.

Metode yang pertama adalah knowledge acquisition. Tahap ini adalah proses pengambilan dan transfer pengetahuan dari pakar penghitungan KPR Bank XYZ ke engineer aplikasi. Pengetahuan yang diambil meliputi cara penghitungan kredit berdasarkan jangka waktu, sistem cicilan dan besarnya suku bunga baik yang fixed maupun indikasi cap atau batas atas suku bunga mengambang.

Metode yang kedua adalah melakukan analisis terhadap kebutuhan pengguna terhadap sistem. Pada tahap ini dilakukan hipotesa dan survey ke beberapa pengguna mengenai aplikasi seperti apa yang sesuai untuk calon konsumen properti. Dari analisis kebutuhan ini diketahui bahwa aplikasi yang paling sesuai adalah aplikasi yang berbasis web karena bisa diakses kapanpun dan di manapun. Dengan aplikasi ini pengguna tidak perlu melakukan instalasi software apapun di sisi client. Karena aplikasi cukup diakses menggunakan browser saja.

Metode berikutnya adalah perancangan database. Perancangan database pada tahap ini hanya membutuhkan database pengguna yang berfungsi untuk login ke dalam aplikasi.

\section{HASIL DAN PEMBAHASAN}

Di dalam metode penelitian di atas disebutkan bahwa aplikasi ini adalah berbasis web, karena itu aplikasi yang akan dikembangkan, akan menggunakan bahasa pemrograman $P H P$, software database management system menggunakan MySQL dan web server menggunakan Apache. Jadi dalam implementasi, yang menjadi tahap pertama adalah mempertimbangan pemilihan kombinasi PHP, MySQL, dan Apache. Pertimbangan ini adalah bahwa kombinasi ini, selain paling banyak digunakan, juga dianggap paling cepat dan efisien untuk melakukan transfer request data dari pengguna ke server dan sebaliknya transfer response dari server ke pengguna.

Skema pembiayaan berbasis cicilan yang diimplementasikan oleh dunia perbankan pada dasarnya ada berbagai macam. Dalam aplikasi ini, skema yang diterapkan mirip dengan apa yang disebut dengan skema murabahah dalam pembiayaan KPR yang dilakukan oleh bank-bank syari'ah. Perbedaan dengan bank syari'ah hanya pada tataran filosofi atas pembagian keuntungan saja. Di mana pembagian keuntungan inilah yang dikonversikan menjadi suku bunga dalam bank XYZ.

Haris (2007:117) dalam penelitiannya menjelaskan skema murabahah dalam pembiayaan KPR seperti dalam Gambar 1 dan penjelasannya sebagai berikut: 


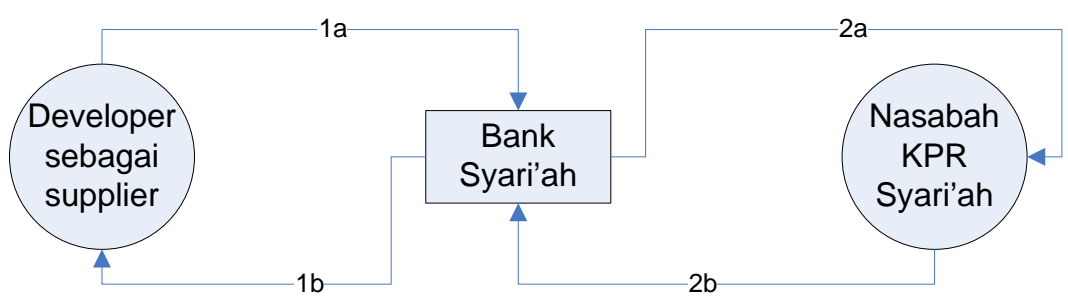

Gambar 1 Skema pembiayaan KPR Syari'ah dengan skim murabahah

\section{Keterangan:}

1a. Developer perumahan menjual rumah kepada pihak bank syari'ah secara tunai.

1b. Bank syari'ah membeli kepada developer selaku supplier secara tunai.

2a. Bank syari'ah menjual rumah sebesar harga pokok/asal ditambah keuntungan yang disepakati bersama, kepada nasabah KPR syari'ah secara tangguh/angsuran

2b. Nasabah membeli kepada bank syariah secara angsuran

Skema pembiayaan KPR oleh bank XYZ kepada calon konsumen properti mirip dengan skim murabahah pada bank syari'ah. Hanya saja berbeda pada filosofi pada pembagian keuntungan sehingga proses pembiayaan ini lebih cenderung pada proses hutang-piutang antara calon konsumen properti dengan bank XYZ. Untuk lebih jelasnya, secara konseptual skema pembiayaan KPR oleh bank XYZ adalah seperti dalam Gambar 2 sebagai berikut:

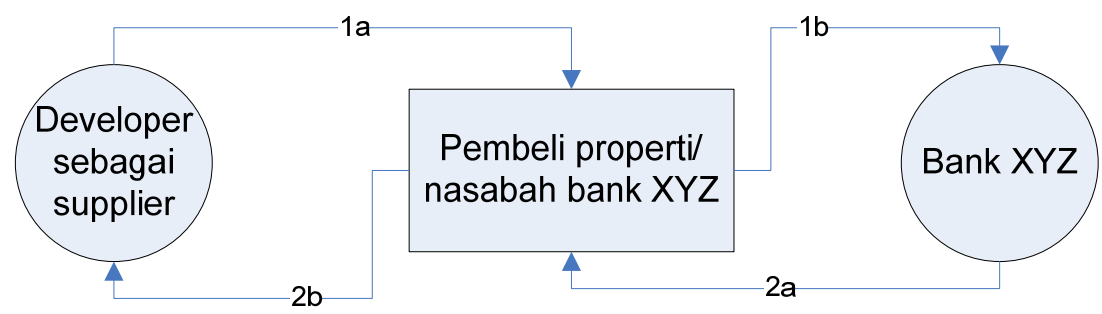

Gambar 2 Konsep skema pembiayaan KPR bank XYZ

\section{Keterangan:}

1a. Developer perumahan menjual rumah kepada nasabah bank XYZ.

1b. Konsumen mengajukan pinjaman ke bank XYZ senilai harga rumah dikurangi uang muka.

2a. Bank XYZ memberi pinjaman ke konsumen dan nasabahnya sebesar harga pokok/asal dikurangi uang muka. Pembayaran hutang secara cicilan berdasarkan model sistem KPR yang ditawarkan bank XYZ ke konsumen.

2b. Konsumen membayar harga properti ke developer.

Tahap kedua adalah merancang proses sequence atau urutan untuk mengakses aplikasi ini secara online. Langkah pertama adalah bahwa pengguna harus login terlebih dahulu. Bagi pengguna yang belum punya akun bisa melakukan registrasi terlebih dahulu sebelum login. Alternatif selain login berbasis registrasi, adalah login menggunakan akun facebook. Jadi aplikasi ini juga terkoneksi 
dengan data akun facebook melalui application programming interface (API) yang disediakan oleh facebook. Langkah kedua adalah pelanggan memilih tipe properti yang akan dibeli oleh pengguna dan nilai atau harga properti tersebut. Dalam aplikasi ini disediakan empat jenis pilihan tipe properti, yaitu rumah, apartemen, rukan atau ruko, dan tanah. Langkah ketiga adalah pelanggan memilih jangka waktu pembayaran cicilan dan besarnya uang muka. Untuk jangka waktu cicilan dalam aplikasi ini disediakan lima pilihan, yaitu lima tahun, sepuluh tahun, limabelas tahun, duapuluh tahun, dan duapuluh lima tahun. Sedangkan untuk pembayaran uang muka juga disediakan lima pilihan, yaitu 10\%, 20\%, 25\%, 30\%, dan 40\%. Langkah terakhir adalah pelanggan memilih sistem KPR yang ditawarkan. Pada aplikasi ini ada dua model sistem KPR, yang pertama adalah berbasis kombinasi suku bunga fixed and cap dan yang kedua berbasis suku bunga fixed untuk dua tahun pertama. Yang membedakan kedua model tersebut adalah cara penghitungan suku bunga KPRnya. Untuk model yang pertama, yaitu fixed and cap, adalah sistem yang menerapkan suku bunga tetap selama periode tertentu dengan kombinasi dengan suku bunga mengambang, yaitu suku bunga yang mengikuti suku bunga yang berlaku di pasar, namun ditentukan capnya, yaitu batas atasnya atau besarnya suku bunga maksimum. Suku bunga adalah sejumlah rupiah yang dibayar akibat telah mempergunakan dana sebagai balas jasa (Aryaningsih, 2008:59). Perubahan suku bunga merupakan perubahan dalam permintaan uang (kredit) (Aryaningsih, 2008:59). Dalam aplikasi ini, bank XYZ, mengenakan suku bunga tetap selama tiga tahun pertama secara berturut-turut sebesar 9,75\%. Pada tahun keempat dan kelima mengenakan suku bunga sebesar $10 \%$. Dan pada tahun keenam dan berikutnya mengenakan suku bunga mengambang dengan indikasi cap ditentukan 12\%. Untuk model yang kedua, yaitu fixed dua tahun, bank XYZ menerapkan suku bunga tetap selama dua tahun pertama secara berturut-turut sebesar $8,5 \%$ dan pada tahun ketiga dan berikutnya menetapkan suku bunga mengambang dengan indikasi ditentukan sebesar $12 \%$. Proses logical dari langkah-langkah penghitungan KPR dalam aplikasi ini bisa dilihat seperti dalam Data Flow Diagram (DFD) pada Gambar 3 di bawah ini. Sedangkan untuk menggambarkan urutan langkah-langkah proses physical dalam proses penghitungan KPR adalah menggunakan diagram flowchart seperti dalam Gambar 4 di bawah ini:

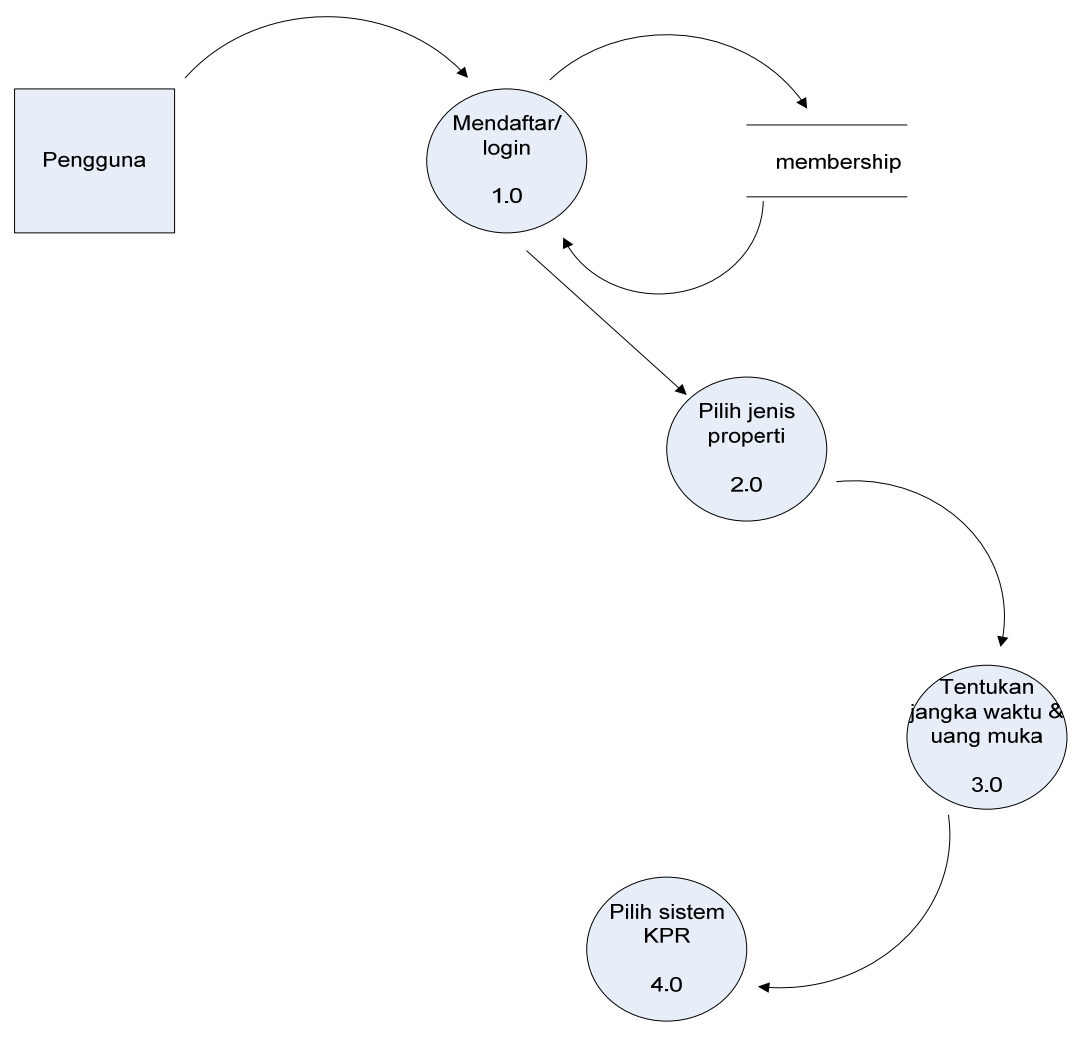

Gambar 3 DFD logical proses penghitungan KPR 


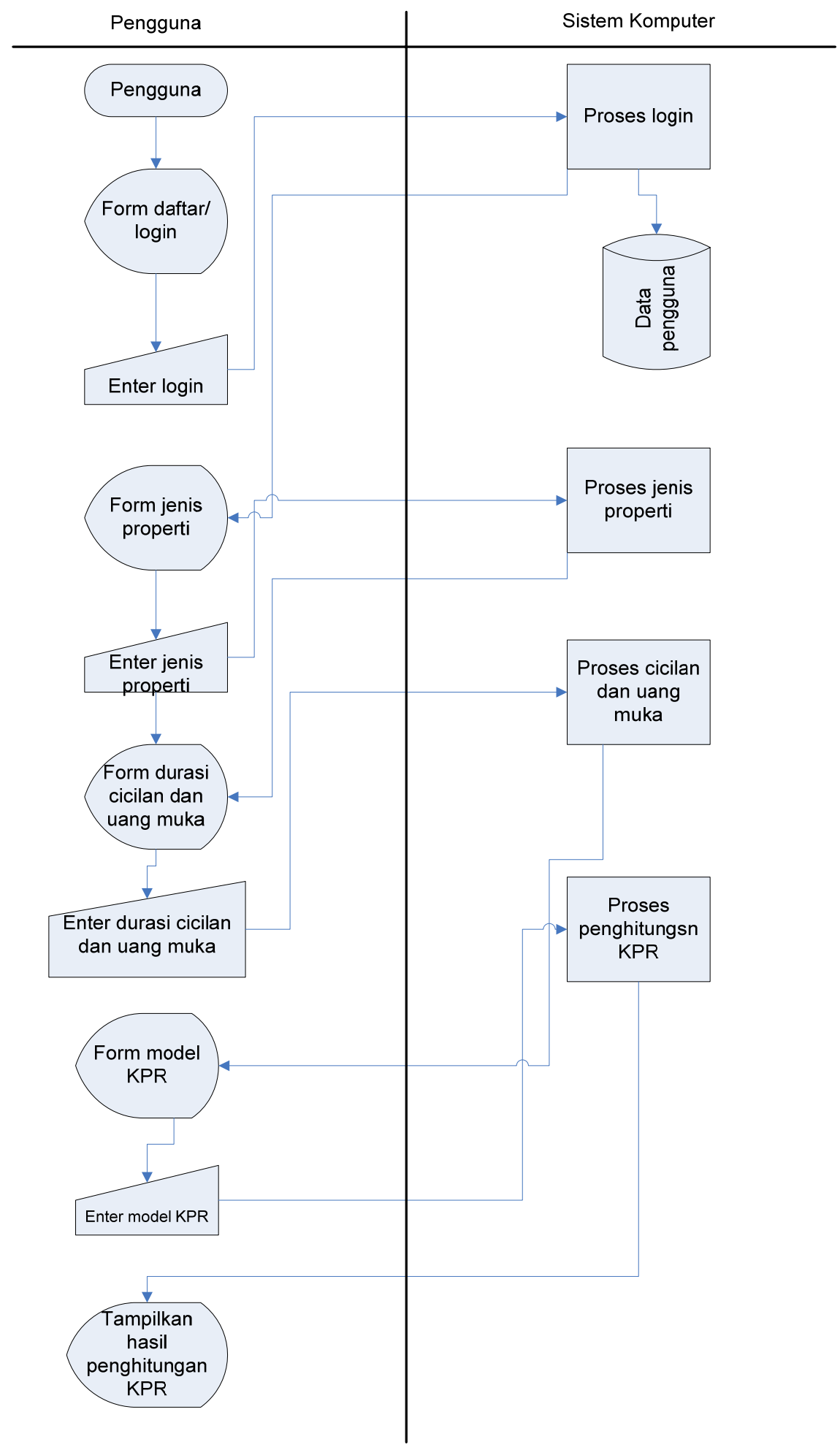

Gambar 4 Flowchart proses penghitungan KPR

Setelah keempat langkah tersebut dijalankan, pengguna bisa mendapatkan angka atau nilai hasil penghitungan setelah menekan tombol hitung. Screenshot ilustrasi user interface setelah hasil akhir penghitungan adalah seperti terlihat dalam Gambar 5 di bawah: 


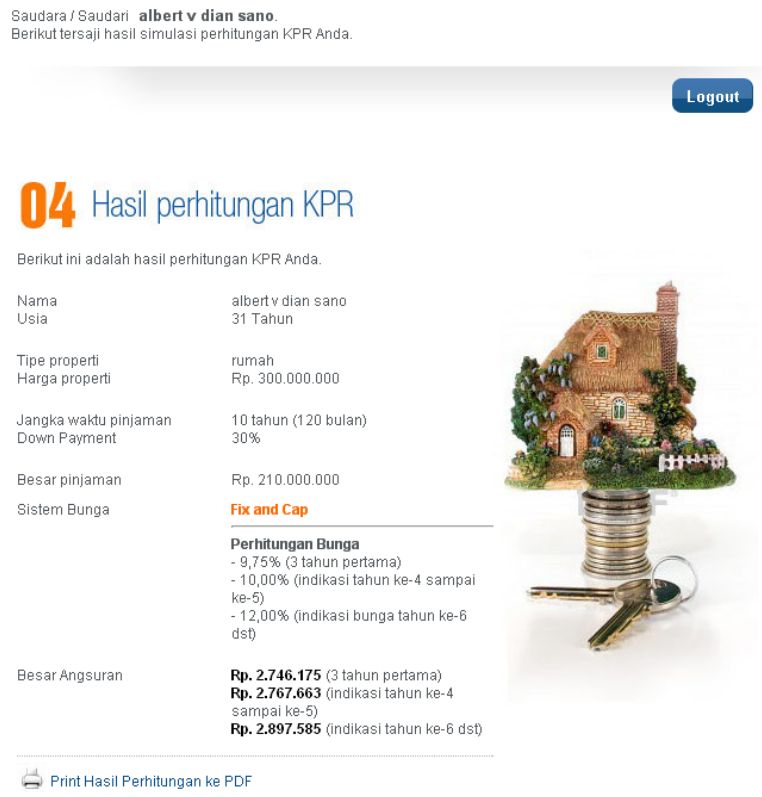

Gambar 5 Ilustrasi user interface untuk penghitungan KPR

Tahap ketiga adalah implementasi database pengguna untuk login. Database ini memiliki tiga tabel yang berfungsi untuk menangkap data pengguna, yaitu tabel member_tb, tabel member_detail, dan tabel kpr_user. Tabel member_tb dan tabel member_detail berfungsi untuk menyimpan data pengguna yang melakukan registrasi di portal finansial www.kontan.co.id. Selain login berdasarkan membership, pengguna juga diberi alternatif untuk login menggunakan akun facebook dan secara otomatis men-share melalui status wall di facebook bahwa pengguna sudah menggunakan aplikasi penghitungan KPR dari bank XYZ di portal finansial www.kontan.co.id. Tabel kpr_user berfungsi untuk menangkap data kombinasi dari data pengguna dan data yang berasal dari facebook. Sehingga, tabel kpr_user untuk aplikasi ini juga menampung field-field data yang diambil dari facebook melalui API. Data yang diambil adalah id facebook dan access token. Id facebook digunakan untuk membentuk sesi selama pengguna berada dalam aplikasi ini sedangkan access token digunakan untuk mendapatkan akses aplikasi ini ke facebook supaya aplikasi bisa di share kembali melalui status wall pengguna di facebook. berikut:

Tabel logical untuk tabel member_tb, tabel member_detail, dan tabel kpr_user adalah seperi

tabel member_tb $=\{\#$ m_id, username, password, status, date_active $\}$.

tabel member_detail = \{\#d_id, nama_lengkap, jenis_kelamin, tanggal_lahir, alamat, kota, propinsi, Negara, email, telepon, hp, gaji, jabatan, industry, besar_perusahaan, m_id, email_confirm, email_status\}. jabatan\}.

tabel kpr_user $=\{\#$ \#id, fb_id, access_token, nama, email, tanggal_lahir, gender, pekerjaan,

Field dengan tanda '\#' adalah berfungsi sebagai Primary Key (PK). Untuk deskripsi tipe data adalah seperti yang terlihat dalam Tabel 1, Table 2, dan Table 3 berikut:

Tabel 1 Nama-nama field dan tipe data tabel member_tb

\begin{tabular}{ll}
\hline \multicolumn{1}{c}{ Nama field } & \multicolumn{1}{c}{ Tipe data } \\
\hline m_id & $\operatorname{int}(10)$ \\
\hline username & varchar(40) \\
\hline
\end{tabular}




\begin{tabular}{ll}
\hline password & varchar(32) \\
\hline status & $\operatorname{int}(1)$ \\
\hline date_active & date \\
\hline
\end{tabular}

Tabel 2 Nama-nama field dan tipe data tabel member_detail

\begin{tabular}{ll}
\hline \multicolumn{1}{c}{ Nama field } & \multicolumn{1}{c}{ Tipe data } \\
\hline d_id & int(10) \\
\hline nama_lengkap & varchar(50) \\
\hline jenis_kelamin & varchar(10) \\
\hline tanggal_lahir & date \\
\hline alamat & varchar(255) \\
\hline kota & varchar(30) \\
\hline propinsi & varchar(30) \\
\hline negara & varchar(30) \\
\hline email & varchar(50) \\
\hline telepon & varchar(20) \\
\hline hp & varchar(20) \\
\hline gaji & int(5) \\
\hline jabatan & varchar(30) \\
\hline industri & varchar(50) \\
\hline besar_perusahaan & int(5) \\
\hline m_id & int(10) \\
\hline email_confirm & varchar(32) \\
\hline email_status & int(1) \\
\hline
\end{tabular}

Tabel 3 Nama-nama field dan tipe data tabel kpr_user

\begin{tabular}{lc}
\hline \multicolumn{1}{c}{ Nama field } & Tipe data \\
\hline id & int(11) \\
\hline fb_id & int(11) \\
\hline access_token & Varchar(100) \\
\hline nama & Varchar(255) \\
\hline email & Varchar(255) \\
\hline tanggal_lahir & date \\
\hline gender & Varchar(25) \\
\hline pekerjaan & Varchar(255) \\
\hline jabatan & Varchar(255) \\
\hline
\end{tabular}

Hasil uji coba untuk hasil akhir penghitungan KPR dalam aplikasi ini sudah valid dan sesuai dengan formula hasil transfer pengetahuan dari Bank XYZ. Aplikasi ini sudah di coba lebih dari 1000 pengguna.

Keunggulan aplikasi ini adalah bahwa aplikasi ini bisa diakses kapanpun dan di mana pun sepanjang pengguna memiliki koneksi internet. Jadi aplikasi ini sangat menghemat waktu pengguna karena tidak perlu lagi mencari informasi baik ke pihak pemberi kredit atau ke pihak penjual properti mengenai besarnya cicilan, cara menghitung cicilan, atau model KPR yang ditawarkan. Keuntungan yang lain lagi adalah bahwa aplikasi ini juga sangat membantu pengguna dalam mengambil keputusan mengenai model cicilan mana atau jangka waktu terbaik mana yang akan diambil oleh calon konsumen properti. Keputusan terbaik oleh calon konsumen properti bisa di dapatkan dengan cara 
mencoba berbagai macam variasi penghitungan dan membanding-bandingkan berbagai macam kemungkinan variasi penghitungan dalam aplikasi ini.

Kekurangan aplikasi ini adalah bahwa model pembayaran cicilan sudah ditentukan hanya dua model saja oleh bank XYZ, yaitu yang pertama fixed and cap dan yang kedua fixed dua tahun, sehingga alternatif lain diluar itu tidak ada. Kelemahan lain lagi adalah besarnya suku bunga cicilan sudah ditentukan baik yang fixed and cap dan fixed dua tahun ditetapkan sesuai dengan suku bunga yang berlaku di bank XYZ. Sehingga kemungkinan berbagai variasi suku bunga yang mungkin saja berbeda dari bank lain tidak bisa dihitung dalam aplikasi ini. Kelemahan ini bisa diselesaikan bila suku bunga cicilan dalam aplikasi ini di rancang sebagai variable, dan variabel ini bisa di-input-kan oleh pengguna.

\section{PENUTUP}

Aplikasi ini berjalan dengan baik dan hasil proses penghitungan KPR juga valid dan sudah digunakan oleh lebih dari seribu pengguna.

Aplikasi ini sangat bermanfaat bagi pengguna yang akan membeli properti. Manfaat yang didapatkan adalah bahwa pengguna atau calon konsumen bisa lebih cepat dan efisien dalam menghitung cicilan dan menentukan model KPR yang akan dipilih. Ujung dari manfaat ini adalah bahwa pengguna atau calon konsumen properti lebih mudah dan cepat dalam mengambil keputusan berkaitan dengan perencanaan keuangan pribadinya.

Kekurangan dari aplikasi ini adalah bahwa suku bunga cicilan sudah ditetapkan dengan nilai tertentu dan tidak sebagai variabel yang bisa di-input-kan oleh pengguna. Sehingga pengguna tidak bisa mencoba variasi suku bunga di luar yang sudah ditentukan.

Untuk meningkatkan portabilitas, aplikasi ini memiliki potensi untuk dikembangkan lebih lanjut secara khusus dengan desain yang spesifik untuk diakses oleh berbagai macam handheld devices dengan berbagai macam aplikasi berbasis mobile apps, misalnya apps berbasis sistem operasi android, ios, symbian, windows mobile, dan lain-lain.

\section{DAFTAR PUSTAKA}

Amri, AB., Indreswari, AD., Dori, MA., (2012). DP Kredit Properti 30\%, Kelas Menengah Jadi Tumbal. Diakses 14 Agustus 2012 dari http://fokus.kontan.co.id/news/kelas-menengahtumbal-uang-muka-kredit-properti/2012/07/10.

Aryaningsih, NN. (2008). Pengaruh suku bunga, inflasi dan jumlah penghasilan terhadap permintaan kredit di PT BPD cabang pembantu Kediri. Jurnal Penelitian dan Pengembangan Sains \& Humaniora, 2(1), 59.

Campbell, J.Y., Cocco, J.F. (2010). A Model of Mortgage Default. Diakses 16 Agustus 2012 dari http://scholar.harvard.edu/campbell/files/mortdefault24112010.pdf.

Haris, H. (2007). Pembiayaan kepemilikan rumah: sebuah inovasi pembiayaan perbankan syari'ah. Jurnal Ekonomi Islam: La_Riba, 1(1), 117.

Keown, A. J. (2010). Personal Finance: Turning Money into Wealth. New Jersey: Pearson Education. 